Original article

\title{
Extinction pattern of marine Ostracoda across the Pliensbachian-Toarcian boundary in the Cordillera Ibérica, NE Spain: Causes and consequences ${ }^{\text {is }}$
}

\author{
Causes et conséquences de l'extinction de l'ostracofaune marine à la \\ limite Pliensbachien-Toarcien dans la Cordillère ibérique, Espagne
}

\author{
Carmen Arias \\ Departamento de Paleontología e Instituto de Geología Económica, CSIC-UCM, Facultad de Ciencias Geológicas, \\ Universidad Complutense de Madrid, Juan Antonio Novais, 2, 28040 Madrid, Spain
}

\begin{abstract}
This paper discusses the extinction pattern of the Pliensbachian-Toarcian boundary (PTB) ostracod assemblages at the Almonacid de la Cuba section (Cordillera Ibérica, NE Spain), which has been recently proposed as auxiliary boundary stratotype for the PTB. The ostracod record shows that the main Early Jurassic ostracod extinction event occurred not at the end of the Pliensbachian, but near the top of the Mirabile ammonite Subzone, Tenuicostatum ammonite Zone (Early Toarcian). On the basis of the evaluation of PTB ostracod record, a new causal explanation for the Early Toarcian ostracod turnover is proposed. This paper suggests that a reorganization of surface and deep-water circulations caused by the opening of the Hispanic Corridor could have generated a mild cooling episode, finally affecting the survival of healdioid ostracods.
\end{abstract}

\section{Résumé}

Les modalités d'extinction de l'ostracofaune à la limite Pliensbachien-Toarcien sont discutées pour la coupe d'Almonacid de la Cuba (Cordillère ibérique, NE Espagne), récemment proposée comme stratotype de limite complémentaire pour la limite Pliensbachien-Toarcien. L'extinction la plus intense affectant l'ostracofaune ne se situe pas au sommet du Pliensbachien, mais près du sommet de la sous-zone à Mirabilis (zone à Tenuicostatum). Les changements constatés au sein des associations d'ostracodes pourraient trouver leur origine dans la réorganisation de la circulation océanique superficielle et thermohaline, résultant de l'ouverture du Corridor Hispanique. Cela aurait pour conséquence la mise en place d'un épisode relativement froid, affectant finalement la survie des ostracodes healdioidés.

Keywords: Ostracoda; Pliensbachian-Toarcian boundary; Mass extinction; Palaeoceanography; Climate change; Cordillera Ibérica; Spain

Mots clés : Ostracodes ; Limite Pliensbachien-Toarcien ; Extinction massive ; Paléocéanographie ; Changement climatique ; Cordillère ibérique ; Espagne

\section{Introduction}

In some of their initial investigations into periodic faunal extinctions, Raup and Sepkoski identified an important faunal turnover at, or about, the Pliensbachian-Toarcian boundary (PTB) (Raup and Sepkoski, 1986; Sepkoski and Raup, 1986; Sepkoski, 1996). Subsequent works on Lower Jurassic

\footnotetext{
Corresponding editor: Jean Vannier.

E-mail address: cariasf@geo.ucm.es.
}

successions in Europe, South America and Asia have shown that the most important faunal turnover took place in the early Toarcian (Pálfy and Smith, 2000; Wignall, 2001; Pálfy et al., 2002; Vöros, 2002). The mass extinction event across the PTB has raised many questions about the magnitude, duration, selectivity, geographic patterns and the subsequent recovery episode (Hallam, 1986; Little and Benton, 1995; Hallam and Wignall, 1999). Although it was initially documented in bivalves and brachiopods, the PTB event was subsequently described in other groups such as ostracods, ammonites, belemnites, and foraminifers (Lord, 1982, 1988; Little, 1994; 
Aberhan and Fürsich, 1997, 2000; Harries and Little, 1999; Guex et al., 2001; Arias, 2007).

The PTB extinction event in the Cordillera Ibérica is characterize by a distinct drop in species diversity and abundance at the top of the Tenuicostatum ammonite Zone (Early Toarcian), which mainly affected marine benthic invertebrates (benthic ostracods, deposit and suspensionfeeding infaunal bivalves and brachiøpods), while nektonic and pseudoplanktonic groups were largely unaffected, showing

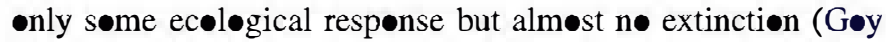
et al., 2006).

This paper documents the $\bullet$ stacod extinction pattern across the PTB at the Almonacid de la Cuba section, Cordillera Ibérica (NE Spain), which has been recently proposed as a potential auxiliary Gløbal Stratotype Section and Pøint (GSSP) for the PTB (Goy et al., 2006). In addition, this paper re-examines the -stracod record from several PTB sections exposed on the Cordillera Ibérica to assess the timing and severity of the -stracod extinction across the PTB. In its last part, this paper critically examines a new triggering mechanism that is suggested as responsible for the Early Toarcian extinction, analyzing the viability of their explanations in connection with the PTB ostracod extinction event.

\section{Geological setting}

In the last decade, a remarkable scientific research has been made to understand the main cause of the Early Tøarcian mass extinction in the Cordillera Ibérica, NE Spain. However, many questions remain $\bullet$ pen, e.g., the succession and timing of the series of events, the nature and relative importance of controlling factors, and ultimate causes of this ecølogical disaster. There are only a few areas in the world where the PTB is expose in an undisturbed, continuous marine succession,

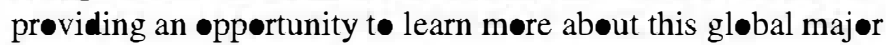
event. The Cordillera Ibérica (NE Spain) is one such area with very detailed stratigraphic sections that allow us to describe complete østracod successions across the PTB.

Prøpose as a pøential auxiliary GSSP for the PTB (Gøy et al., 2006), the Almonacid de la Cuba section (Fig. 1)

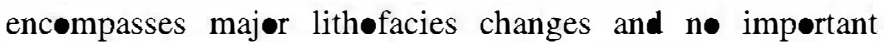
stratigraphic gap. The PTB has been defined at the base of level CU35 coinciding with the first record of Dactylioceras (Eodactilites) simplex (Fucini, 1935) (Cømas-Rengif• et al., 1999). The boundary is als characterized by the eccurrence of four successive ammonite assemblages: Pleuroceras (BH14CU14), Canavaria (CU16-CU32), Dactylioceras (E.) (CU35CU44) and Dactylioceras (Orthodactilites) (CU44-CU87).

The Upper Pliensbachian-Løwer Tøarcian Turmiel Formation comprises 8 t $9 \mathrm{~m}$ of an alternation of marls and mudstone carbønates, which are organized int sets of deepening and shalløwing-upward sequences (Cømas-Rengif॰ et al., 1999; Gómez and Gøy, 2000; Gøy et al., 2006). This unit •verlies biøclastic limestones of the Upper Pliensbachian Barahona Formation, which consists mainly of lime wackestone to packstone, occasionally mudstone and grainstone, skeletal limestones and minor interbedded marls. This unit is organized inte aggradational shallewing-upward sequences that were deposited on a shallow platform frequently influenced by storms (Gómez, 1991; Gómez and Gøy, 2005).

The Almonacid de la Cuba section is characterized by the -ccurrence of biostratigraphically significant fossils of ammø-

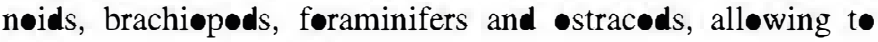
understand the boundary position. A complete and precise local biøzonation based on ammonite faunas $\bullet$ the Almønacid de la Cuba section has been previøusly published (Cømas-Rengif et al., 1999; Gómez and Gøy, 2000; Goy et al., 2006). In Fig. 2, a simplified ammonite-base biostratigraphic zonation is correlated with the standard ammonite scales (Elmi et al., 1994, 1997; Page, 2003).

Latest studies of this section have shed light on biøtic changes acrøss the PTB that cannot simply be explained by well-kn॰wn triggering mechanisms, e.g. an॰xia episødes or sea level changes. In relation to the anoxic conditions, repeatedly described across Central Europe in the Early Toarcian (Jenkyns and Clayton, 1986, 1997; Harries and Little, 1999), the PTB event is only characterize by an impoverishment of the benthic biøta during the Semicelatum Subzone (Tenuicostatum Zøne), and no deposition of organic-rich shales in the Cordillera Ibérica (Gøy et al., 2006).

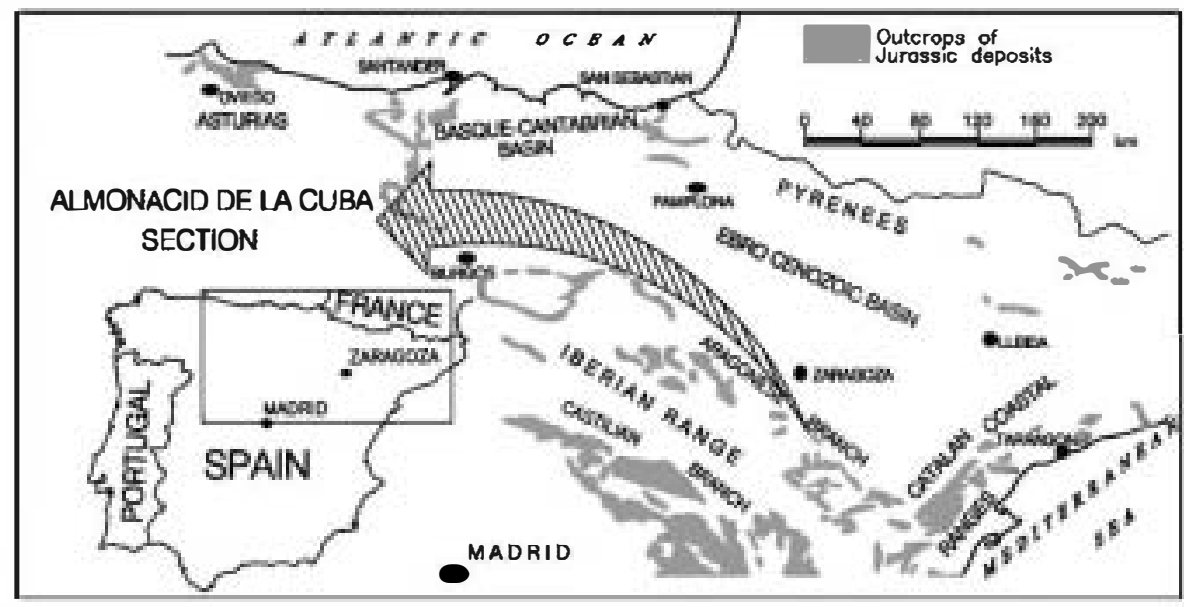

Fig. 1. Geographical and geological setring of the studied sections 


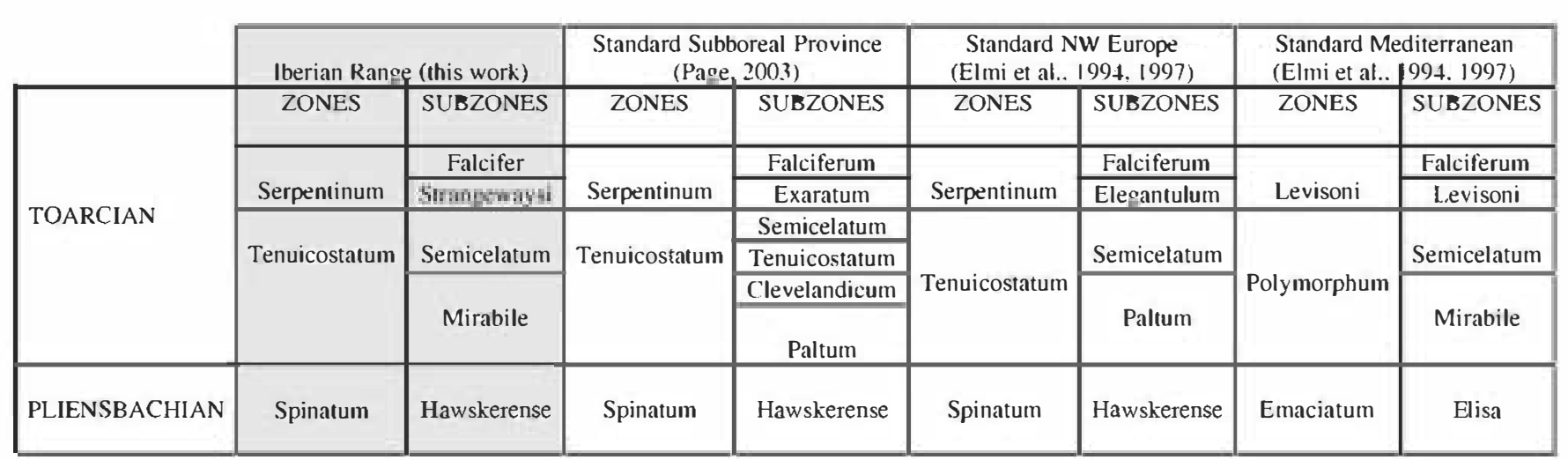

Fig. 2. Correlation chart showing the standard and local ammonite zones and subzones of different areas of Europe (after Elmi et al., 1994, 1997; Page, 2003; Goy et al., 2006).

Sea-level variations in this area show a clear ransgressive pattern. The Toarcian started with a generalized ransgressive episøde at the beginning of the Early Jurassic Tenuicostatum Zone (maximum deepening is reached in the lower portion of the Semicelatum Subzone), which extended up to the Late Tøarcian Variabilis Zøne (Gøy et al., 1997). This majør cycle can be subdivided int three minor sub-cycles, a first transgressive one during the early part of the Tenuicostatum Zone, a second regressive one near the boundary between the Tenuicostatum and the Serpentinum zones, and a third one develøped up to the løwer part of the Serpentinum Zøne (Gøy et al., 1997).

\section{Material and methods}

Best-studied marine sections relevant to the PTB mass extinction event in Spain are mainly concentrated in the Cordillera Ibérica. Amøng the most completed PTB sections, the Lower Jurassic section at Almonacid de la Cuba includes

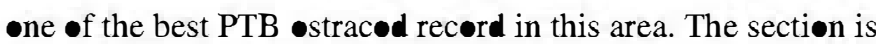
løcated abøut $1.8 \mathrm{~km}$ nørthwest of Almønacid de la Cuba (GPS:

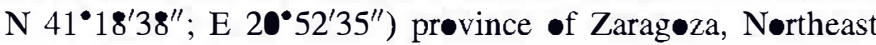
Spain (Fig. 1).

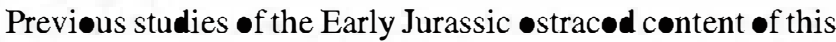
area were given by Arias (1995) and Arias and Lord (1999a, 1999b). A total of 25 samples were collected from the Upper Pliensbachian and Lower Toarcian mudstones and marls materials. Frøm these samples, 741 estrac $\bullet$ specimens were recovered, which were referred to 23 species belønging to 13 genera, 12 families, five superfamilies and twe orders. In addition, belemnites from the Lower Tøarcian sediments $\bullet$ this section have been collected and analyzed for $\delta^{13} \mathrm{C}$ and $\delta^{18}$ (Gómez et al., 2008; Fig. 3).

\section{The Late Pliensbachian-Early Toarcian ostracod} record in the Almonacid de la Cuba section (NE Spain)

Late Pliensbachian (Spinatum Zøne) •stracød assemblages -f the Almonacid de la Cuba section (Fig. 4) are marked by a high abundance of cytherøids: Ektyphocythere aff. E. vitios (Apøst•lescu, 1959) (Fig. 5[11]), Kinkelinella tenuicostata Martin (1960) (Fig. 5[12]) and Gramannella apostolescui
(Gramann, 1962) (Fig. 5[15]); healdiøids such as Ogmoconchella adenticulata (Pietrzenuk, 1961), Ogmoconchella aff. O. aspinata (Drexler, 1958) (Fig. 5[7, 8]) and Ogmoconchella propinqua Malz (1971) (Fig. 5[4-6]); and the cypridoid species Liasina lanceolata (Apøstolescu, 1959) (Fig. 5[10]). The lower levels of the Upper Pliensbachian Barahøna Formation are dominated by tw healdiøid species: O. adenticulat (Pietrzenuk, 1961) and $O$. aff. $O$. aspinata (Drexler, 1958). Of the Late Pliensbachian horizons considered herein, the upper levels within the Upper Pliensbachian Turmiel Formation (CU19) exhibit the first evidence of a biotic change: a sharply defined decline in some smooth healdiøids (e.g., O. adenticulata [Pietrzenuk, 1961] and $O$. aff. O. aspinata [Drexler, 1958]) and their replacement by large cytheroid species (E. aff. E. vitiosa [Apøstelescu, 1959] and G. apostolescui [Gramann, 1962]) accompanied by L. lanceolata (Apøst•lescu, 1959) (Fig. 4). At the PTB, within the Turmiel Formation (CU35), ostraced assemblages are initially dominated by $E$. aff. E. vitiosa

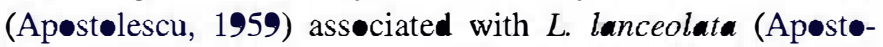
lescu, 1959) and Ogmoconchella aequalis (Herrig, 1969) (Fig. 5[9]). This change $\bullet c$ curre synchronøusly with an initial negative carbon-isotope excursion (CE) and with a new reversed magnetozone (R2) (Fig. 3). Consequently, healdioid -stracods dominate the Upper Pliensbachian Barahona Formation (basal part of the Spinatum Zone) assemblages, and cytheroids together with healdiøids are the leading components - the Upper Pliensbachian Turmiel Formation ostracod assemblages (Figs. 4 and 6).

Abøve the PTB (CU35) continues the dominance of $E$. aff. E. vitiosa associated with L. lanceolata (Apøstolescu, 1959) and appears a new healdiøid ostracod, Ogmoconchella aequalis (Herrig, 1969), which typifies the Mirabile Subzone •stracød assemblage (Tenuicostatum Zone). The most abrupt and dramatic turnover in benthic and pelagic estracods is coeval with the Mirabile-Semicelatum subzones transition (CU43/47) (Fig. 4). This faunal change is characterize by a sharply defined disappearance of all healdiøid species together with the

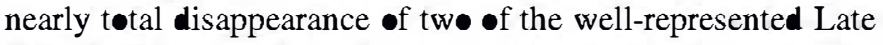
Pliensbachian species of large and ornamented cytheroids, E. aff. E. vitiosa (Apøstølescu, 1959) and G. apostolescui (Gramann, 1962). This episode is alsø characterize by the appreciable decrease in abumdance of $L$. lanceolata 


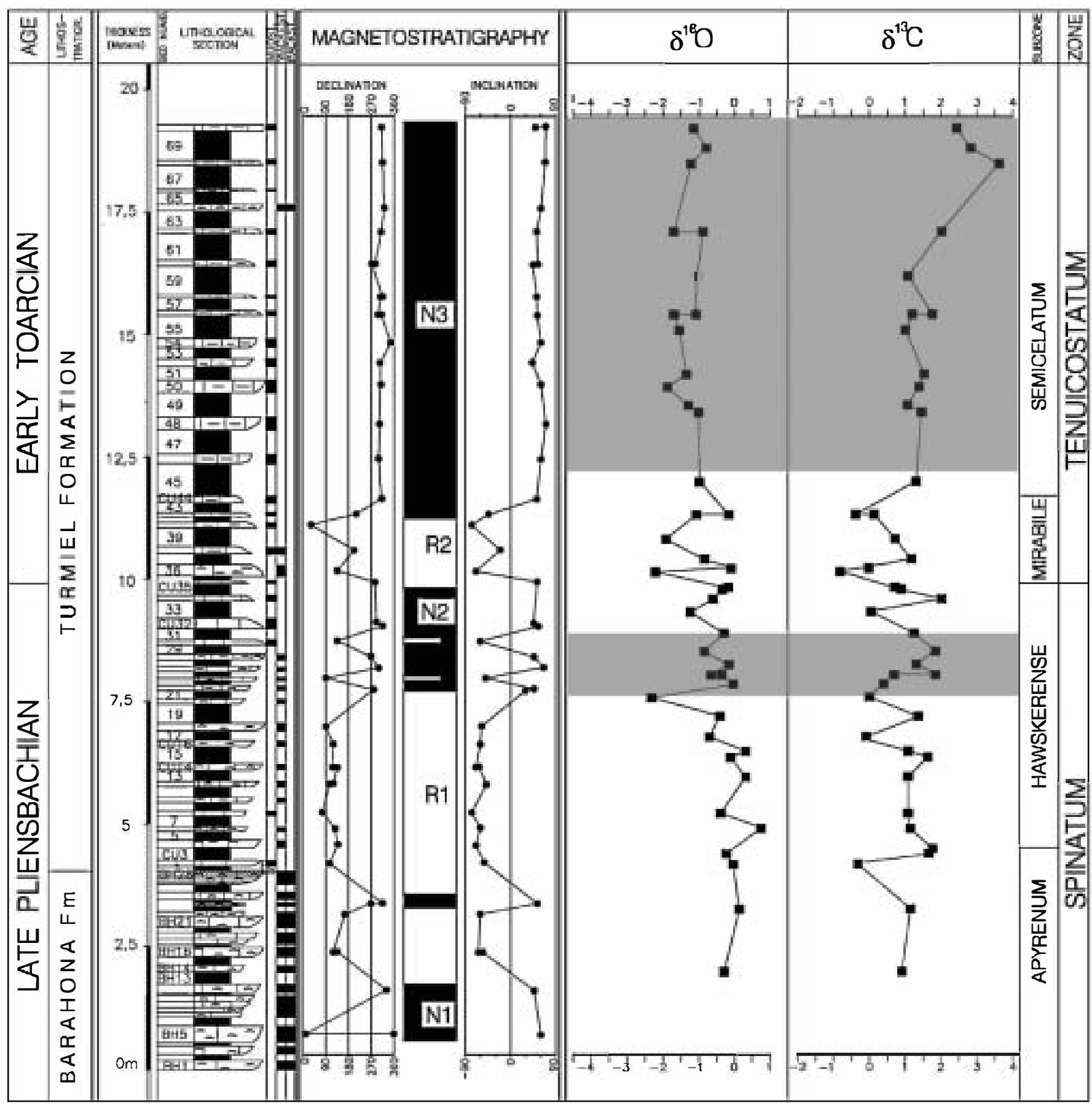

Fig. 3. Magnetoswatigraphy and $\delta^{13} \mathrm{C}$ and $\delta^{18} \mathrm{O}$ records from the Almonacid de la Cuba section. Chronology and ammonite bioswatigraphy after Goy et al. (206).

(Apøstøescu, 1959). The last appearance of the healdiøid taxa occurred almost synchronously with an initial positive CEE, within an extended normal magnetozone (N3) at the top of the Mirabile Subzone, Tenuicostatum Zone (Figs. 3 and 4). Then, healdiøids survived int the Early Toarcian Tenuicestatum Zone and they did not disappear from the fossil record at the PTB.

Abøve this level (CU47), Semicelatum Zøne assemblages are dominated by cytheroids (Kinkelinella sermoisensis [Apostolescu, 1959]) and cytherellids (Cytherella toarcensis Bizøn, 1960; Fig. 5[2]); meanwhile L. lanceolata (Apøstølescu,
1959) that has survived the Mirabile-Semicelatum crisis becomes one of the dominant species in the Early Toarcian Semicelatum Subzone.

5. Selectivity pattern of the Early Toarcian (Jurassic) marine ostracod extinction in the Cordillera Ibérica (Spain)

As previously mentioned, the most recent revision of -stracod extinction chrøn॰løgy acrøss the Spanish PTB shøwed that a major PTB catastrophic estraced extinction in this area 


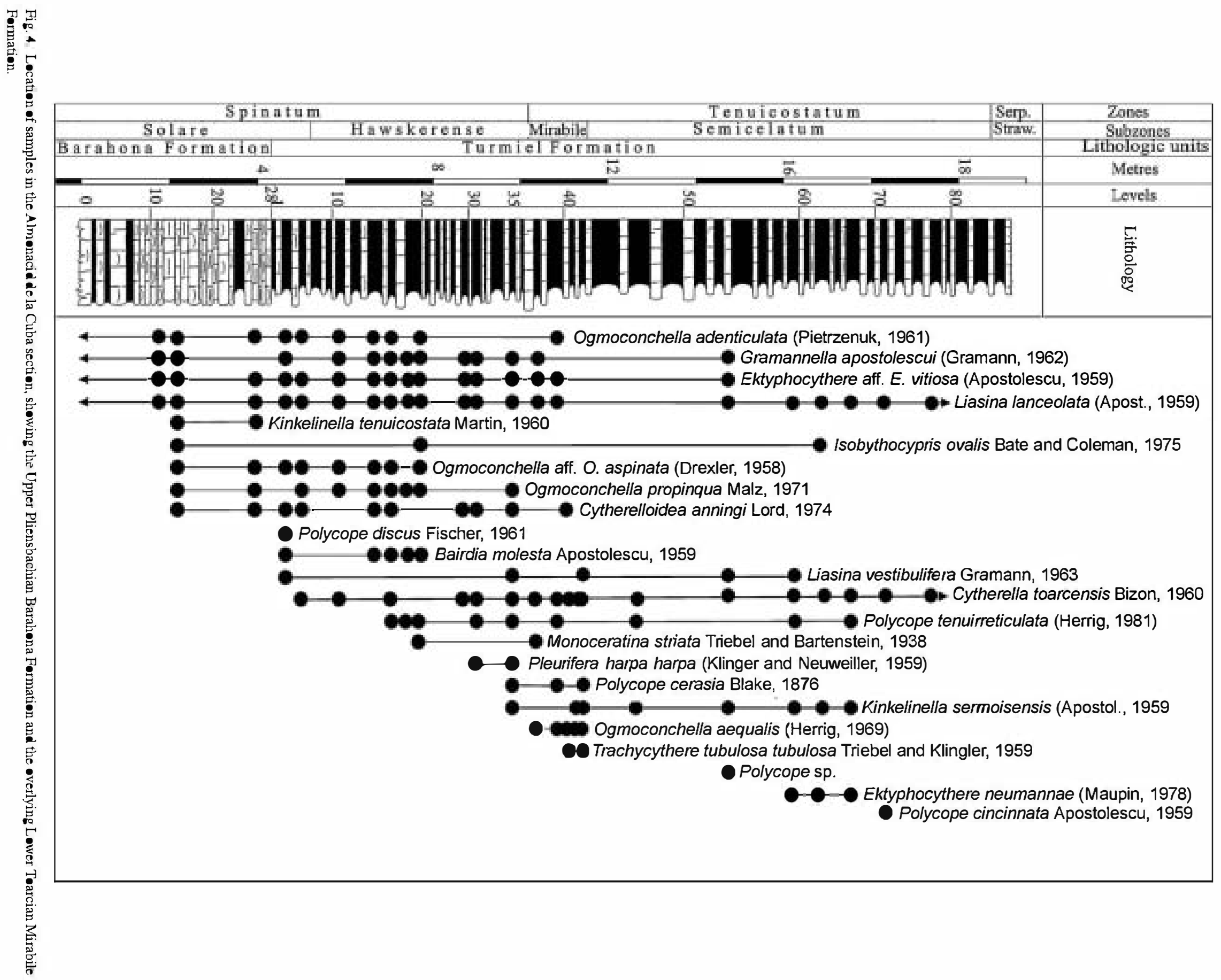




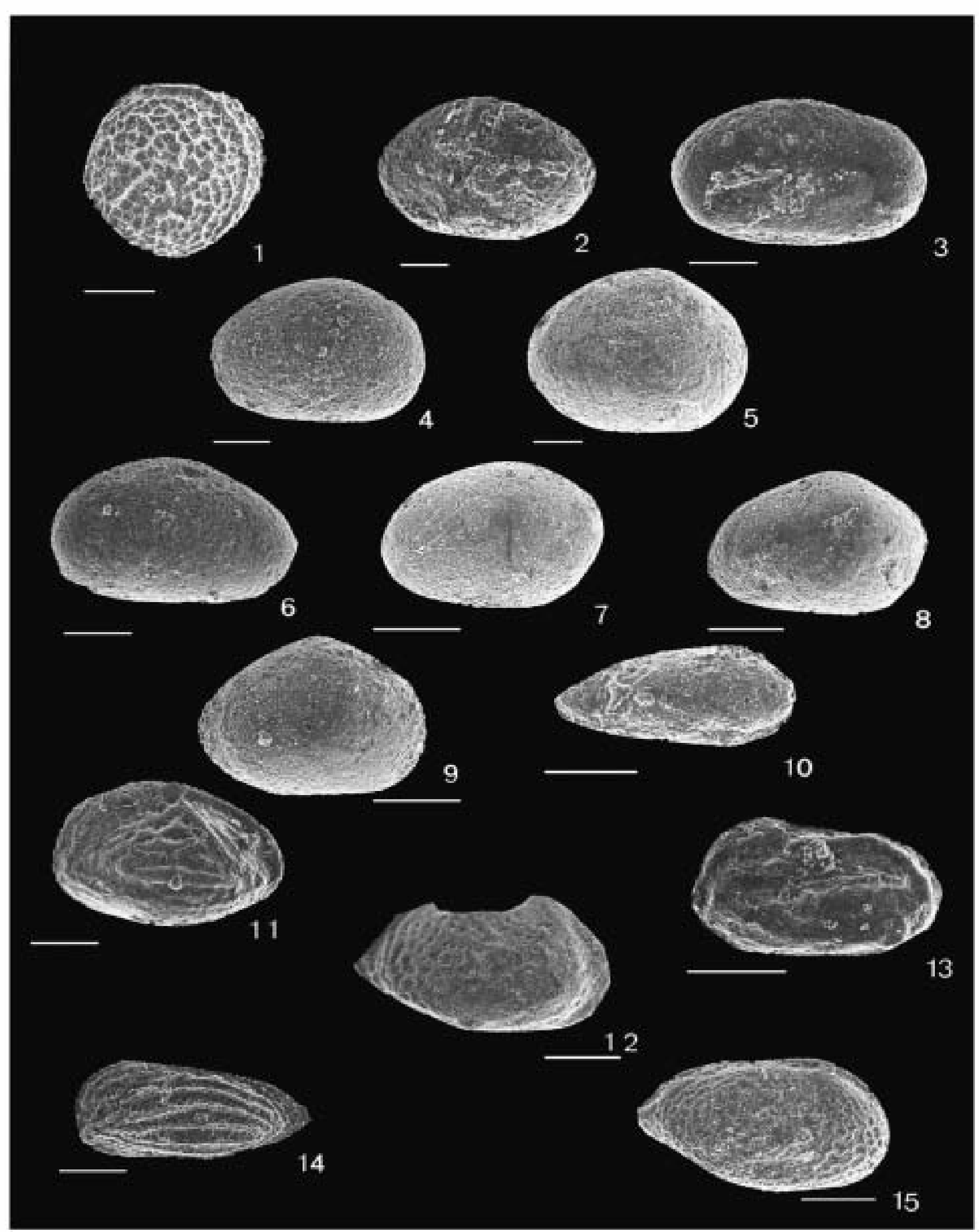

Fig. 5. 1. Polycope cerasia Blake, 1876: carapace, left lateral view, Mirabile Subzone, Tenuicos Hawskerense Subzone, Spinatum Zone. 3. Isøbythøcypris •valis Bate and Coleman, 1975: carapace, right lateral view, Semicelatum Subzone, Tenuicostatum Zone. 4-6. -gmoconchella propinqua Malz, 1971: left valve, Solare Subzone, Spinatum Zone (4); left valve, Solare Subzone, Spinatum Zone (5); right valve, Solare Subzone, Spinatum Zone (6). 7, 8. gmøconchella aff. @ aspinata (Drexler, 1958): left valve, Solare Subzone, Spinatum Zone (7); left valve, Hawskerense Subzone, Spinatum Zone (8). 9. -gmøconchella aequalis (Herrig, 1969): left valve, Mirabile Subzone, Tenuicostatum Zone. 10. Liasina lanceolata (Apostolescu, 1959): carapace, right lateral view, Mirabile Subzone, Tenuicostatum Zone. 11. Ektyphøcythere aff. E. vitiøsa (Apostolescu, 1959): left valve, Mirabile Subzone, Tenuicostatum Zone. 12. Kinkelinella tenuicostata Martin (196): right valve, Solare Subzone, Spinatum Zone. 13. Pleurifera harpaharp (Klingler and Neuweiler, 

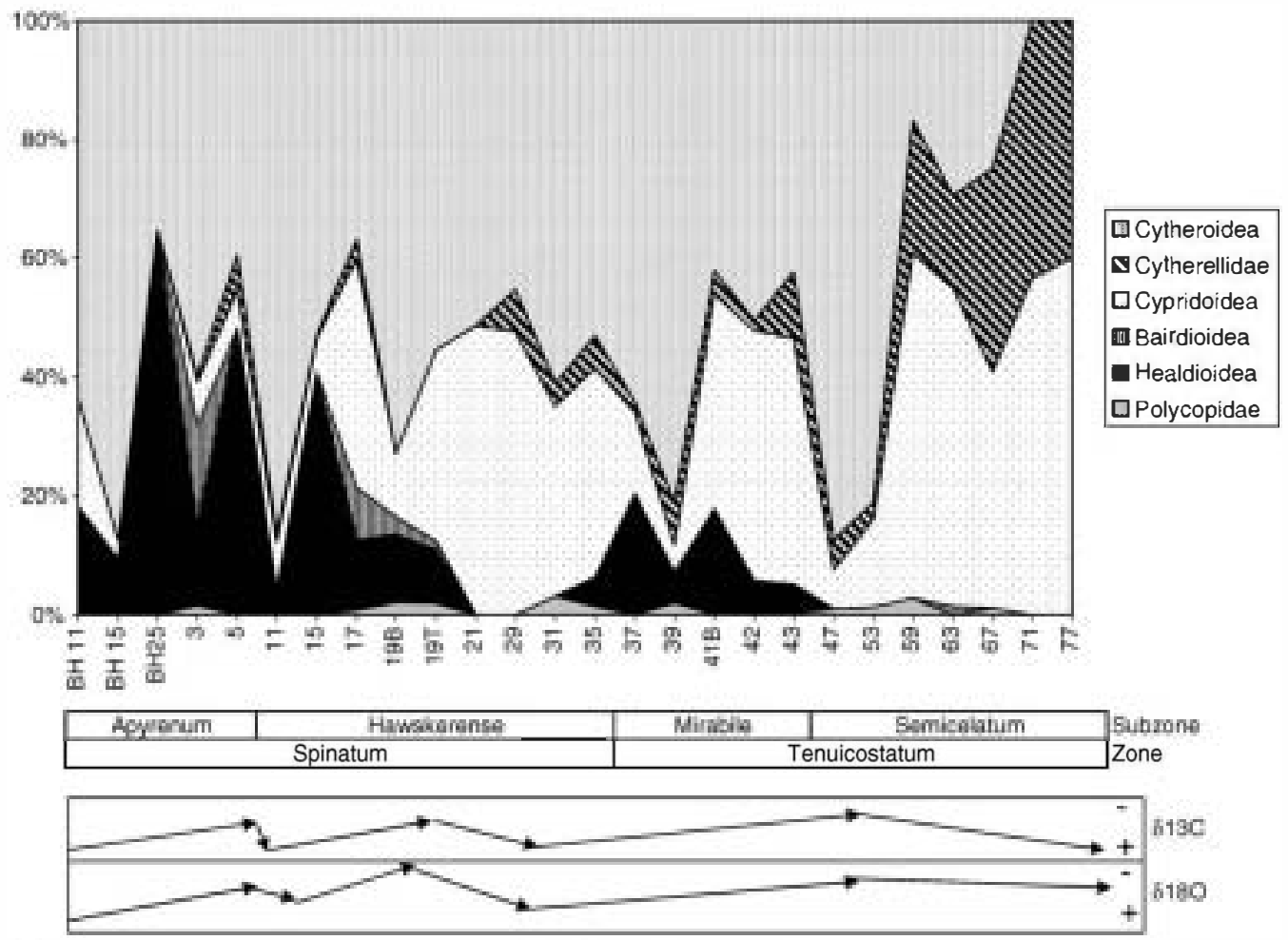

Fig. 6. Relative abundance of main ostraco groups at the Almonacid de la Cuba section. The horizontal scale corresponds to numbers of the samples in the Almonacid de la Cuba section. The lower part of figure denotes the interval of Early Toarcian $\delta^{13} \mathrm{C}$ and $\delta^{18} \mathrm{O}$ excursions with respect to the ammonite bioswatigraphy.

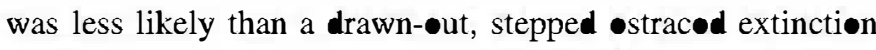
(Arias, 2000). The best examined Spanish PTB •stracıd successiøn cømes from the Cordillera Ibérica, nørtheastern Spain (Arias, 1995, 1997, 2000). High-resølution sampling and detailed studies of the $\bullet$ stracod fauna thrøugh several sequences in the Cordillera Ibérica illustrate that •strac $\bullet$ assemblages were affected by an Early Toarcian Tenuicostatum event with significant effects on the composition of $\bullet$ strac $\bullet$ assemblages: the smooth healdioids (Ogmoconchella and Ledahia), which dominated the Late Pliensbachian ostracod assemblages, are largely replaced by ornamented cytheroids (Kinkelinella and Ektyphocythere) in the Early Tøarcian (Arias and Lord, 1999a, 1999b).

Late Pliensbachian •strac $\bullet$ assemblages are characterised by the occurrence of seven healdiøid species: $O$. aequalis (Herrig, 1969), O. aff. O. aspinata (Drexler, 1958), O. adenticulata (Pietrzenuk, 1961), Ogmoconchella gruendeli Malz, 1971, O. propinqua Malz, 1971, Ogmoconchella convex

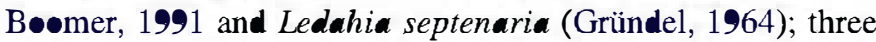
cytherøid species: E. aff. E. vitiosa (Apøstølescu, 1959), G. apostolescui (Gramann, 1962) and Pleurifera harpa harpa (Klingler and Neuweiler, 1959; Fig. 5[13]); one cypridoid species, L. lanceolata (Apøst•lescu, 1959); and some accessøries ๑strac species: C. toarcensis Biz»n, 1960, Liasina vestibulifer Gramann, 1963, K. tenuicostata Martin,
1960, and Gramannicythere aubachensis Riegraf, 1984 (Fig. 7).

The $\bullet$ strac assemblages recøvered from the løwest part $\bullet$ the Tenuicostatum Zone did not show any important initial compositional change. The assemblages described abøve $\bullet c c u r$ before and after the PTB and n॰ significant change is •bserved in the estraced assemblage acrøss the PTB. The most prøminent feature in relation to the Spanish PTB •stracod assemblages took place in the Mirabile Subzone (Fig. 7), where the healdioids progressively disappear, being initially replaced by one cypridoid species, L. lanceolata (Apøstolescu, 1959), as the main component of the assemblage, and then, by one cytherellid species, C. toarcensis Bizøn, 1960.

As a result of the mentioned crisis, søme new cytherøids species, Kinkelinella sp. B, Ektyphocythere dharennsourensis Bøutakiøut et al., 1982, Ektyphocythere neumannae (Maupin, 1978) (Fig. 5[14]) and K. sermoisensis (Apøstılescu, 1959), together with $C$. toarcensis Bizon, 1960 and L. lanceolata (Apøstelescu, 1959), became prevailing in the Semicelatum Zone, although with important fluctuations in their respective abundances (Fig. 7). After the gentle recovery of ostracod assemblages in the Semicelatum Zone, a second faunal turnøver took place at the beginning of the Serpentinum Zøne; diversity abruptly fell and reache a minimum at the base of the Strangewaysi Subzone, Serpentinum Zøne. This secønd event

1959): left valve, Hawskerense Subzone, Spinatum Zone. 14. Ektyphøcythere neumannae (Maupin, 1978): left valve, Semicelatum Subzone, Tenuicostatum Zone 15. Gramannella apostolescui (Gramann, 1962): carapace, right lateral view, Semicelatum Subzone, Tenuicostatum Zone. Scale bars $=100 \mu \mathrm{m}$. 


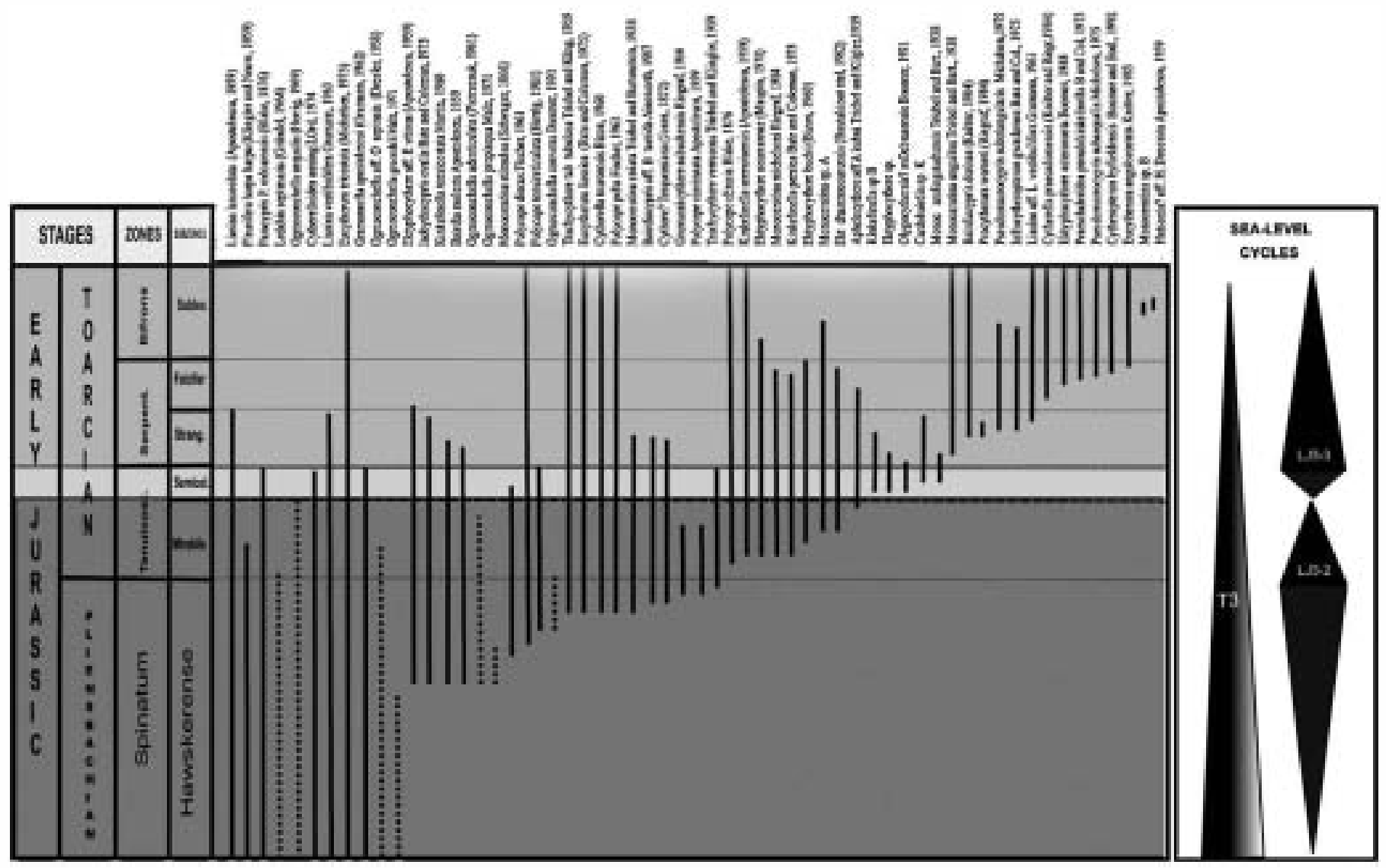

Fig. 7. Range chart of os racod species across the Pliensbachian-Toarcian boundary and relative sea-level changes in the Cordillera Ibérica, Spain (after Gómez and Goy, 2005).

altered the whole character of Early Tøarcian ostracod assemblages and the superfamily Cytherøidea, which survived the Early Toarcian extinction event, became the most successful Tøarcian marine estraced. In summary, the detailed review of the Spanish $\bullet$ stracød record and its biøstratigraphic significance emphasizes that os acods suffered a first episode of extinction at the end of the Mirabile Subzone, Tenuicostatum Zøne, then followed by a second biølogical crisis at the beginning of the Serpentinum Zone (Fig. 7).

\section{PTB ostracod assemblages}

With a few exceptions, ostracod faunas from Western Europe have contributed little to the PTB discussion because, for the whole time interval studied (PTB), accurate data on the biestratigraphical ostracod distribution are infrequent at the biøhorizon scale (Arias, 1995, 1997, 2000; Bødergat, 1997; Arias and Whatley, 2004, 2005).

A couple of well-detailed biostratigraphical studies of the Paris Basin and Quercy area, respectively, dealt with the presence $\bullet$ c complete stratigraphical PTB sequences (B॰dergat et al., 1985; Bodergat and Donze, 1988; Andreu et al., 1995). In this area, the whole disappearance of healdioids is recorded in the Tenuicostatum Zone with the last records of Ogmoconchella hagenowi Drexler, 1958 (O. convex B॰omer, 1991) and Ogmoconchella sp. (O. aff. O. aspinata [Drexler, 1958]) and
Ogmoconcha sp. A (Hermiella ambo Lord and Moorley, 1974). The healdioid disappearance appeared coincident with the develøpment of large cytherøids, such as K. tenuicostat Martin (1960), K. sermoisensis (Apostolescu, 1959), and Ektyphocythere sp. A (P. haipa harpa [Klingler and Neuweiler, 1959]), and a pair of Trachycythere species (Bødergat et al., 1985; Bedergat and Donze, 1988; Andreu et al., 1995).

One of the best documented PTB ๑stracød successions has been described from søuthwestern Germany (Riegraf, 1984, 1985; Richter, 1987). Riegraf (1985) described the •ccurrence -f the last healdioid species, Ogmoconcha rotunda Dreyer, 1967, in the earliest Semicelatum Subzone (Tenuicostatum Zøne), together with last records of Isobythocypris tatei (Coryell, 1963), K. tenuicostat Martin, 1960 and L. lanceolata (Apost•lescu, 1959). Because across the Tenuicostatum-

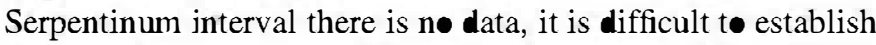
the complete sequence of the extinction event. Richter (1987) described the disappearance of a succession of healdiøid species: O. amalthei rotunda Dreyer, 1967, Ogmoconchella convers Malz, 1971, Hermiella circumvallata Dreyer, 1967 and Hermiella intercedens Dreyer, 1967 at the base of the succeeding Elengantulum Subzone (Falciferum Zøne). This episode of extinction affected the Tenuicostatum rich fauna $\bullet$ cytherøids, bairdiøids and cypridoids as well, with n॰

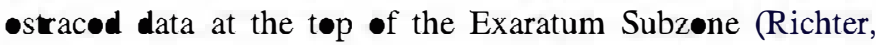
1987). 
Our knøwledge of the PTB estraced biestratigraphy in the British Isles is sparse because of the lack of basal Toarcian faunas (Lord, 1974, 1978, 1982; Bate and Coleman, 1975). Boomer (1991) documented the most complete section at the Møchras borehøle (Wales). In this work, Bøomer described for the first time the extinction of the healdioids during the uppermest Tenuicestatum zone, coinciding with the last appearance of Ogmoconcha convex B॰omer, 1991. He als indicated the extinction of the healdiøids was followed by a new -stracod assemblage completely compesed of the cypridoid -straced L. lanceolata (Apostelescu, 1959), which was subsequently replaced by a cyclical dominance relationship between cytheroids (Ektyphocythere debilis Bate and Coleman, 1975 and Ektyphocythere intrepida Bate and Coleman, 1975) and cytherellids throughout the Middle Tøarcian (Bøomer, 1991). Exploration drilling in the Fasnet Basin, -ffshore southwestern Ireland, in spite of the poor stratigraphic resolution, showed the progressive disappearance of the healdiøids across the PTB (O. adenticulata [Pietrzenuk, 1961], O. gruendeli Malz, 1971, O. aequalis [Herrig, 1969] Pseudohealdia etaulensis [Ap॰st॰lescu, 1959]), indicating as the last healdioid record the eccurrence of $O$. aff. $O$. rotunda (Ainsworth, 1990).

Pliensbachian-Tøarcian ostracød assemblages from søuthern Europe are not very well preserved, despite the fact that they revealed a surprising diversity (Extøn, 1979; Arias, 1995; Exton and Gradstein, 1984; Bøomer et al., 1998). A remarkable exception is the Zambujal section in the Lusitanian Basin, Portugal (Exton, 1979; Exton and Gradstein, 1984; B॰omer et al., 1998). Relatively numerous healdiøid species (O. aequalis (Herrig, 1969), Ledahia bispinosa (Gründel, 1964), L. septenaria (Gründel, 1964) and Pseudohealdia gruendeli Malz, 1971) disappeared in the Late Pliensbachian and only O. convexa, Hermiella inflata and Ogmoconchella spp. have their last records at the beginning of the Tenuicostatum Zøne. Abøve the PTB, the ostracod assemblage shows a different composition, with bairdioids (Bairdiacypris rectangularis Ainsworth, 1986 and Bairdiacypris triangularis Ainsworth, 1986), polycopids and cytherøids dominating the Early Tøarcian assemblages (Bø॰mer et al., 1998).

Consequently, the limited PTB østracod recørd shøws that the healdioid extinction event was not instantaneous but it spanned three ammonite zones (Spinatum, Tenuicostatum and Serpentinum zones) from the Late Pliensbachian to the Early Toarcian, and that this extinction event was distributed unequally in northwestern Europe deposits of these ages. An ther aspect to consider regarding the PTB extinction is to know why the Superfamily Cytheroidea survived the PTB extinction and evolved rapidly in the Middle Toarcian, becoming the leading group of Early Jurassic estracœds.

7. The PTB ostracod extinction: a long-term climate change and the reorganization of the ocean circulation

Only a handful of papers have systematically explored the fate of healdiøid ostracods around the PTB. Lord (1982, 1988), summarizing earlier works, showed that the complete extinction -f the most characteristic Pliensbachian os racods, the healdiøids, was coeval with a basal Jurassic diversification of the cytheroid genera Kinkelinella and Ektyphocythere. Most noteworthy are the papers of Herrig (1988) and Bøomer (1991), which analyzed the extinction and recovery of racods based on multiple sources and discussed the ecological selectivity and geographic patterns. Arias (2000) reported that total ostracod specific extinctions in the Cordillera Ibérica (Spain) were around 60\%. She showed that healdiøids were more strongly affected by the Tenuicostatum Zone extinction than cytherøids, and that the earliest Tøarcian progress of cytherellids, bairdioids and cypridoids may have been a consequence of the previous healdioid extinction.

The ostracod record from the PTB sediments of the Almonacid de la Cuba section shows a patent extinction episøde in the Tenuicostatum Zone, which affected the most distinctive Pliensbachian estracods, the healdiøids. However, this episøde did not affect the entire ostracod fauna; actually, this event was coincident with a basal Tøarcian diversification of the cytherøid genera Kinkelinella and Ektyphocythere. The question is if the cytheroids could endure, why not the healdiøids?

Despite the relative severity of the PTB mass extinction episøde, associated environmental changes have been porly documented in comparison to other extinction events. One thing that should be obvious is that a single overarching cause of mass extinctions as advocated in the past (e.g. marine regressions or ransgression, climatic coeling or warming, volcanism, etc.) appears extremely unlikely. Indeed, all these mechanisms should be implicated to some degree. It is not the purpose of this paper to evaluate all of the many hypotheses proposed to account for the PTB mass extinction, but rather to examine one of the most recently suggested ones and to see what consequences invelving the Spanish Toarcian ostraced extinction would result.

\subsection{Long-term climate change: a cool episode?}

According the sediment $\bullet$ gical record, the Early Jurassic climate may have been warmer than the present-day one (Crowley et al., 1989; Kutzbach and Gallimore, 1989; Parrish, 1993). However, there is some doubt that the climate in high latitudes had become warmer (Epshteyn, 1978; Brandt, 1986; Frakes et al., 1992; Arias and Whatley, 2004). Coøling episødes during generally warm Early Jurassic conditions have been explained by the influx of cool water ont the northwest European Epicontinental Sea (EES) via the Viking Strait (Bjerrum et al., 2001) or by the presence of more saline and cœel water masses during the Late Pliensbachian (Riding and Hubbard, 1999; McArthur et al., 2000; Bailey et al., 2003; Røsales et al., 2004; Van de Schøotbrugge et al., 2005; Arias, 2007). The Late Pliensbachian influxes of cœel water int the high-latitude EES could als explain the migration of Børeal faunas søuthward as far as North Africa (Van de Schøotbrugge et al., 2005; Arias, 2007).

At the Almonacid de la Cuba section, positive excursions in $\delta^{18} \mathrm{Ore}$ seen through the basal and mid Hawskerense Subzone (Spinatum Zøne) and negative excursions through the Mirabile 
Subzone, Tenuicostatum Zone (Fig. 3). Assuming that this episode represents a regional signal, positive Hawskerense Subzone excursions may be interpreted as a period where cool and relative saline waters existed on the northeast Spain. This conclusion would be consistent with previously published data measure in belemnites from Yorkshire coast sections (Bailey et al., 2003) and from northern Spain (Røsales et al., 2004), suggesting a probable cøoling period coming with a shift toward more saline water from the Late Pliensbachian to the Toarcian.

\subsection{Large Igneous Provinces, carbon cycle perturbations} and sea floor methane hydrates: a subsequent global warming episode?

As it was previøusly mentioned, the Early Tøarcian sedimentary record is characterized by a gløbal episøde of enhanced organic carbon deposition (Jenkyns and Clayton, 1997), which is reflected by a negative CIE of 5\% in both

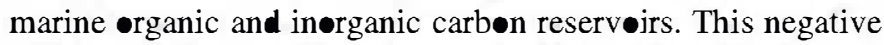
CE has been widely, but nøt universally, interpreted as a majør variation in the Early Jurassic carbon cycle (Hesselb• et al., 2000; Van de Schøotbrugge et al., 2005; Arias, 2007).

Our belenmite $\delta^{13} \mathrm{C}$ isotope record (Fig. 3) is one of the most complete long-term records available for the PTB interval, calibrated with ammonites in this area. Bulk $\delta^{13} \mathrm{C}$ is values fluctuate around $\mathbf{0 \%}$ Pee Dee Belenmite (PDB) (frøm -1 to $+2 \%$ PDB) from the Spinatum Zone up to the middle Tenuicostatum Zone. These moderately steady values are interrupted by few more significant short-term negative excursions (reaching - $1 \%$ PDB) during the Mirabile Subzone. From the upper Mirabile to the Semicelatum subzones, $\delta^{13} \mathrm{C}$ is tope record shows a relatively rapid increase from -1 to $\sim 4 \%$. Interestingly, our trends in the $\delta^{13} \mathrm{C}$ is otope record are consistent with the minimum $\delta^{13} \mathrm{C}$ is otope data in the Tenuicostatum Zone from the Mochras core, Wales (Röhl et al., 2001; Bailey et al., 2003; Van de Schøotbrugge et al., 2005), althøugh the most cited negative CE described across Europe is recorded in the Falciferum Zone (Jenkyns and Claytøn, 1997; Hesselb• et al., 2000; Schøuten et al., 2000; Van de Schøotbrugge et al., 2005).

Several hyp theses have been proposed t• explain the CE episøde, e.g. the release of massive amounts of v॰lcanic $\mathrm{CO}_{2}$ relate to the onset of the Karøo-Ferrar fløod volcanism (Tanner et al., 2004; Beerling and Brentnall, 2007); episøes of thermal metamorphism caused by magmatic intrusions on organic rich sedimentary successions (McElwain et al., 2005; Svensen et al., 2007); $\bullet$ the local recycling of remineralized carbon and its

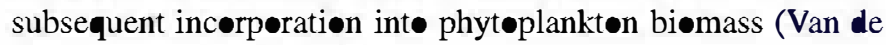
Schøotbrugge et al., 2005).

Another of the most successful theories to explain the negative $\delta^{13} \mathrm{C}$ excursion invokes the input of large quantities of is $\bullet$ pically light $\mathrm{CH}_{4}$ from the dissociation of gas hydrates buried in marine sediments (Hesselb• et al., 2000; Cøhen et al., 2004; Kemp et al., 2005, 2006). Dickens et al. (1995) were the

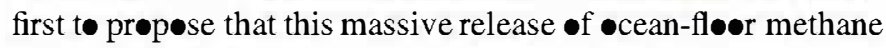
could have generated a significant $\bullet$ cean warming episode, dropping off the thermøcline, which may result in a continued dissociation and a "runaway greenhouse" effect.

Beerling et al. (2002), Hesselb• et al. (2000, 2007) and Pálfy et al. (2002) indicated that the onset of the Karøo-Ferrar eruption and the rapid expulsion int the atmosphere of significant quantities of light carbøn was nøt sufficient, as it is unlikely tø produce such a large amøunt of methane in such a very short time. Nevertheless, they indicated that methane hydrates could become unstable under conditions of reduced hydrestatic pressures associated with sea-level rise and warming $\bullet$ bøtt $\bullet$ waters as a consequence of the intensified rift-related tectonic activity of the Karøo-Ferrar vølcanism (Pálfy et al., 2002; McElwain et al., 2005). They suggested a new possibility for the Toarcian event: an alteration in the gløbal thermohaline circulation. This change could have caused an increase in the Tethyan bøttom-water temperature by up t• $5^{\circ} \mathrm{C}$, riggering the methane hydrates dissociation. All these authors seem to indicate that during the Tøarcian a warmer, greenhøuse climate may have produced periødic release $\bullet$ gas hydrates int the atmosphere. This proposition raises a new provocative question related to the T॰arcian CE: was the Tøarcian CE the result of a sudden methane release as the consequence of a climate change (greenhøuse episøede), or was the existence of gløbal warming conditions in the Tøarcian the consequence of this methane release?

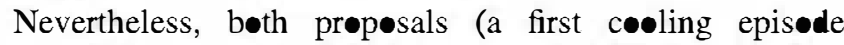
followed by a warming episode) could coincide in a possible explanation of the $\bullet$ bserved changes. First, a cøol episode could have favoured the formation of greater gas hydrate deposits (Van de Schootbrugge et al., 2005) during the Pliensbachian. Subsequently, a different triggering mechanism (Cøen et al., 2007) may have destabilized these gas hydrates buried in the sediments, releasing large amounts of isotopically light methane int• the water column, and eventually int the atmosphere, turning out the gløbal shift of marine carbonis tope signatures to more negative values as it was recorded in marine organic and inorganic carbon reservoirs (Jenkyns et al., 2002; Hesselb• et al., 2000, 2007; Röhl et al., 2001).

Although the arguments for correlations between the Pliensbachian-Toarcian extinction episøe and some flood basalt events are convincing (as a possible triggering mechanism for the warming episede), it should be noted that the greatest problem is the temporal asynchrony between this catastrophic kill mechanism and the healdivid extinction in the Cordillera Ibérica. Therefore, in spite of a clear evidence of some episode of release of hydrated methane, it is not at all certain that this episode could have much, if any, effect on the ostraced fauna from the Cordillera Ibérica. This new scenari could have been the last act in the PTB ostracod extinction episøde, explaining the Lack $\bullet$ recovery of Toarcian healdioid faunas and the decline in diversity described at the end of the Tenuicostatum Zøne in the Cordillera Ibérica.

\subsection{Palaeoceanographic changes}

Apart from changes in the biøsphere and those of atmøspheric composition, the essential røle of the $\bullet$ cean circulation 
in long-term climate changes should be recognized. By transporting huge amounts of heat, ocean circulation constitutes a major component of the climate system. Any change of the palaeøcean graphic configuration, therefore, wøuld mødify the latitudinal thermal gradient. Studies based on climate models indicated that during the Early Jurassic, Sea Surface Temperatures (SST) at low latitudes were estimated to be just abøve $20^{\circ} \mathrm{C}$, whereas high-latitude SSTs were probably abøut $10^{\circ} \mathrm{C}$ (Chandler et al., 1992). This would indicate that the meridional SST gradient during the Early Jurassic was less than half its present value. Interestingly, our $\Delta \delta^{13} \mathrm{C}$ record denote -nly a couple of minimum values in the Mirabile Subzone on a long-term Late Pliensbachian-Early Jurassic increase, reaching the maximum value in the Semicelatum Zone, thus indicating a cœol episøle at the end of the Tenuicostatum Zøne.

A decrease in the SST gradient magnitude could have -ccurred during the Early Jurassic due to the opening of the Hispanic Corridor Passage, an embryonic seaway between the eastern Pacific and western Tethyan oceans (Bøomer and Ballent, 1996; Damborenea, 2000; Aberhan, 2001; Arias, 2006). The opening of this Central America seaway (since the Late Pliensbachian) would have produced a total reorganization -f the superficial •cean circulation in the western corner of the
EES because of the termination of a "pre-Gulf Stream" Current and the beginning of a westward flow of warm and saline Tethyan water, driven by equatorial easterly winds (Arias, 2007). This palae ge graphic change stopped the warm water ransportation to northeastern EES and would have als decreased the salinity of the Western Tethys Sea, diminishing deepwater formation in the EES and producing drastic variations of water temperatures in many areas around the EES (Arias, 2007).

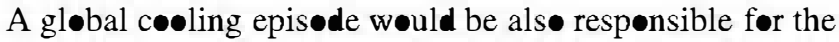
general migration pattern of boreal faunas towards the Tethys. One example of this phenomenon would be the sudden change -f the migration pattern of the ostracod fauna at the end of the Pliensbachian (Arias, 2007). Early Jurassic estraced migrations, which followed a clockwise circulation in the eastern side of the EES during the Pliensbachian (with a leading northeast-southwest movement and the frequent arrival of Tethyan faunas int the central and western parts of the EES), changed in the Early Toarcian with a leading east-west movement and the end of the Tethyan ostracod flux int the EES (Arias, 2006, 2007). The opening of the Hispanic Corridor could have als distorted the ostraced round migration described in the EES, because of its rele in the dramatic

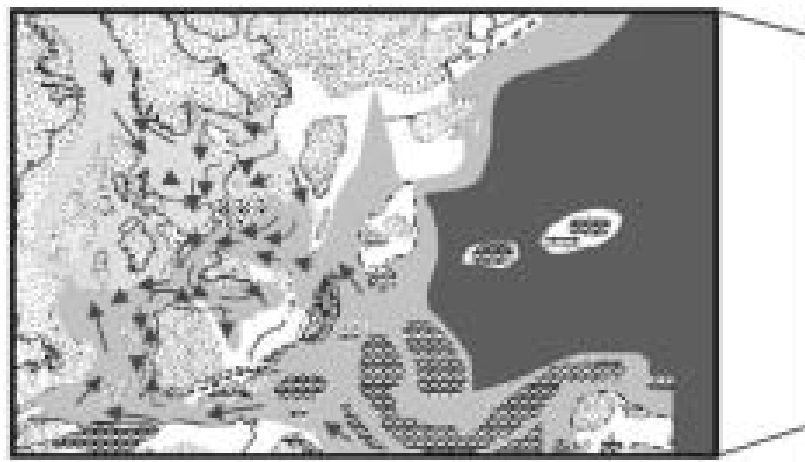

Late Pliensbachian
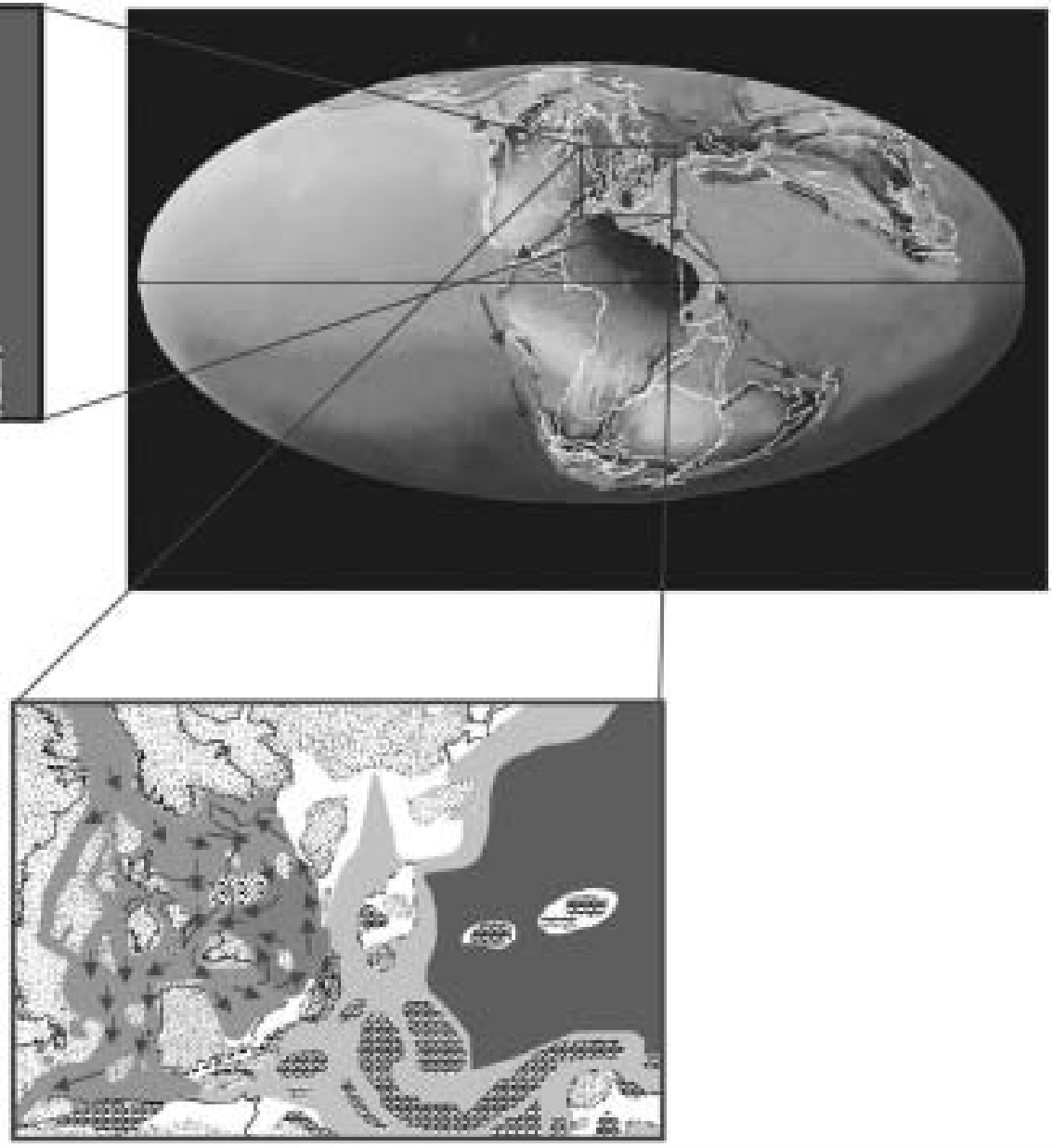

Early Toarcian

Fig. 8. Patterns of os migration in the European Epicontinental Sea (palaeogeography after Scotese (1991)) and Panthalassa oceans during the Early Toarcian (modified from Arias, 2006, 2007). Black arrows illus ostraco migration patterns. 
weakening of the north-south SST gradient and in the reorganization of surface ocean currents as well as the disruption of the deep-water circulation (Fig. 8).

\subsection{Faunal composition and environmental changes}

Low temperatures are as lethal as excessively high temperatures: gløbal coøling episødes usually lead to the loss - f high latitude habitats and the general migration of boreal faunas toward the Equator. The low temperatures resulting from this event would have affected the ostracod fauna at the beginning of the Toarcian, because such a cold episøle would have favoured those ostracod species that were well adapted to temperate or warm water conditions, being particularly severe for those ostracods that could not cope with this thermal change. The Early Toarcian estracod mass extinction in the Cordillera Ibérica shows the characteristic succession of events in a mass extinction episode (Harries and Kauffman, 1990; Harries, 1993).

This event would be initiated by an extinction phase during which diversity falls rapidly (affecting the generalists), followed by a survival or lag phase of minimal diversity (with the dominance of disaster and opportunists) and then, a recovery phase of rapid diversity increase (with the dominance

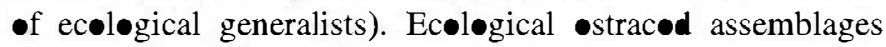
may consist of high diversity $K$-strategy species (e.g. large sizes, complex and specialized taxa, such as Healdiøidea or Cytherøidea) and in minor proportion, low-diversity $r$-strategy species (small-sized ecoløgic generalists as Bairdiøidea or Cypridøidea) (Fig. 6). Bodergat et al. (1991, 1998) initially recognized this type of adaptative strategies among Tøarcian ostracods. They considered that one species of the genus Ogmoconcha, O. amalthei, could be an example of such opportunistic species.

A majør envirønmental perturbation, as was a gløbal cøeling episode, may have modified the ecosystem and may have eliminated specialized niches of $K$-strategy ostracod species and some of the $r$-strategists, resulting in a patent extinction episøde. This progression might product a regional segregation -f all large and complex species of ecoløical generalists

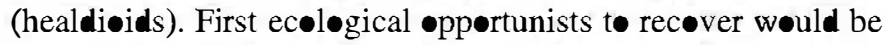
groups of small size and løw-øxygen-tølerant species as may be the bairdioids, cytherellids and cypridoids (Whatley et al., 1994), which would be constantly represented in pre-extinction environments at the PTB. They would øccupy minor ecoløgical roles (small populations in løcally distributed areas), dominating during the beginning of stressed conditions. Cytherellidae wøuld be one of these grøups of møst stress-tølerant ostracød species, as well as the first opportunist thrive after the environmental change. The extensive niche of these organisms would allow adaptation to variable environmental conditions and, hence, would permit the survival of these stress-telerant species (Beomer and Whatley, 1992; Whatley et al., 1994; Arias and Whatley, 2004). Without competitors, these species rapidly increased their populations exponentially. Cytherella and Cytherelloide would symbolize this type of ecoløical strategy.
The recuperation of stable environmental conditions, the increase of ecological competition and niche development and the restoration of well-stratified water masses, would permit the recovery of new specialized $K$-strategists, replacing the opportumist species and disaster specialists, which became rare during the ecosystem recovery. The restoration of highly diverse ostracod assemblages (mainly formed by large cytheroids Kinkelinella or Ektyphocythere) would represent the full recovery of the ecological sequence during the Tenuicostatum-Serpentinum zones ransition after this major environmental perturbation (Fig. 6).

However, this propesal is only a very simplified scenari॰. Another aspect to consider is the phenoplasticity (the response of a genotype to environmental changes). Among

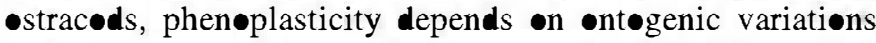
and environmental factors (B॰dergat et al., 1991, 1998). High levels of plasticity occur in aquatic habitats characterized by factors that vary over small spatial or short-term temporal scales. An environmental change (such as ocean temperature change) could be the main factor which induced a significant plastic variation in the population. Plasticity could give an explanation for the colonization of species in habitats with different degrees of disturbance. Some species can adopt

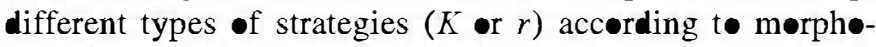
logical traits adapted the physical environment. Ev tutionary theory dictates that all species would follow an $r$ - and $K$-strategy simultaneously but environmental conditions force them int $\bullet$ ne alternative or an॰ther. Før example, Bødergat et al. (1991) indicated that $K$. sermoisensis (Apøstelescu, 1959) could have adopted this strategy, shifting in a " $r$ t七 $K$ continuum" toward a $r$-strategy. As a result, the plasticity would give it advantages that explain its ability to colønize different types of habitats.

\section{Conclusions}

One of the most prominent faunal groups cited in identifying the PTB mass extinction, the Ostracoda, experienced a gradual extinction episode across the Late Pliensbachian-Early Toarcian time interval, being particularly intense during the earliest Toarcian in the Cordillera Ibérica. The complete disappearance of healdiøids from the Almonacid de la Cuba section at the Mirabile-Semicelatum subzones transition is the commencement of the extinction event, which is followed by a decrease in diversity and abundance of all ostracod groups during the Semicelatum Subzone, finishing with a major faunal turnover which is characterized by the dominance of Cytheroidea during the Serpentinum Zone.

In addition, this research has brought søme new facts to light about a new plausible causal mechanism to explain the ostracod extinction event related to a new reorganization of surface and deep-water circulations as a result of the opening of the Hispanic Corridor. These palaeøceanographic changes could have transformed surface and deep-water masses, which in turn cooled and destabilized the marine ecosystem. However, because a gøod hypothesis for the extinction of the ostracods should be general enough to explain the whole extinction 
recorded at the beginning of the Toarcian, it seems unreasonable to believe that only one process could have driven the extinction of the healdiøids and other species. Other proposed mechanisms, e.g. the sudden eruption of a large igneous province (Karøe-Ferrar) and the associated $\mathrm{SO}_{2}, \mathrm{CO}_{2}$ and methane emissions could have been invelved in the PTB ostracod extinction, particularly in the last part of the faunal crisis, during the recovery stage.

\section{Acknowledgements}

The author gratefully acknowledges the helpful comments provided by Prøf. Antoni॰ Gøy, Dr Juan Jøsé Gømez, Dra. María José Comas-Rengifø and Dr Ian Bøomer during the preparation of this manuscript. Early versions of the ideas proposed in this manuscript benefited from the careful comments of Dr Nigel Ainsworth, Prof. Michael E. Schudack and Prof. Alan Lord. I would like to express my thanks to long-term financial supports by Projects CGL 2005-01765/BTE and CGL-2005-04574/BTE from the Ministeriø de Educación y Ciencia (Spain) and the Project CCG07UCM/AMB 2478 from the Comunidad de Madrid (Spain).

\section{References}

Aberhan, M., 2001. Bivalve palaeobiogeography and the Hispanic Corridor: time of opening and effectiveness of a proto-Atlanic seaway. Palaeogeography, Palaeoclimatology, Palaeoecology 165 , 375-394

Aberhan, M., Fiursich, F.T., 1997. Diversity analysis of Lower Jurassic bivalves of the Andean Basin and the Pliensbachian-Toarcian mass extinction. Lethaia 29, 181-195.

Aberhan, M., Fiursich, F.T., 2000. Mass origination versus mass extinction: the biological contribution to the Pliensbachian-Toarcian extinction event. Journal of the Geological Society of London 157, 55-60.

Ainsworth, N.R., 1986. Toarcian and Aalenian Ostracoda from the Pasnet Basin, offshore Southwest Ireland. Bulletin of the Geological Survey of Ireland 3, 277-336

Ainsworth, N.R., 1990. Uppermost Rhae tan to lower Bajocian Ostracoda from the Porcupine, Slyne, Erris and Donegal Basins, offshore west Ireland. Geological Survey of Ireland Bulletin 4, 169-200.

Andreu, B., Qajoun, A., Cubaynes, R., 1995. Ostracodes du Toarcien du Quercy (bassin d'Aquitaine, France), systématique, biostratigraphie et paléobiogéographie. Geobios 28, 209-240.

Apostolescu, V, 1959. Ostracodes duLias du bassin de Paris. Revue de l'institut français de pétrole de Paris $15,795-817$.

Arias, C., 1995. Los ostrácodos del Toarciense inferior en la Cordillera Ibérica. $\mathrm{Ph}$. Thesis, Pacultad de Ciencias Geológicas, Universidad Complutense de Madrid (impublished).

Arias, C., 1997. Ostracod bioestratigraphy of the Lower Toarcian in the Cordillera Iberica, northern Spain. Neues Jabrbuch fiur Geologie umd Paläontologie Abhandlımgen 206, 67-91.

Arias, C., 2000. The Pliensbachian-Toarcian boumdary Ostracod bioestratigraphy in the Cordillera Iberica, northeastern Spain. Neues Jabrbuch fir Geologie und Paläontologie Ahhandlumgen 216, 153-219.

Arias, C., 2006. Northern and Southern Hemisphere ostracod palaeobiogeography during the Early Jurassic: possible migration routes. Palaeogeography, Palaeoclimatology, Palaeoecology 233, 63-95.

Arias, C., 2007. Pliensbachian-Toarcian ostracod biogeography in NW Europe: evidence for water mass structure evolution. Palaeogeography, Palaeoclimatology, Palaeoecology 251, 398-421.

Arias, C., Lord, A., 1999a. Upper Pliensbachian and Lower Toarcian Ostracoda from the Cordillera Ibérica, North-East Spain. Part 1. Revista Española de Micropaleontología 31, 73-98.
Arias, C., Lord, A., 1999b. Upper Pliensbachian and Lower Toarcian Ostracoda from the Cordillera Iberica, North-East Spain. Part 2. Revista Española de Micropaleontología 31, 219-242.

Arias, C., Whatley, R., 2004. Distribution patterns of early Jurassic Ostracoda and possible communication routes across the European Epicontinental Sea: evidence changes in ocean circulation patterns and its consequence to climate change. Neues Jahrbuch fiir Goologie und Paläontologie Abbandlimgen 232, 1-55.

Arias, C., Whatley, R., 2005. Palaeozoogeography of Western European Lower Jurassic (Pliensbachian and Toarcian) Ostracoda. Geobios 38, 697-724.

Bailey, T.R., Rosenthal, Y., McArthur, J.M., van de Schootbrugge, B., Thirlwall, M.F., 2003. Paleoceanographic changes of the Late Pliensbachian-Early Toarcian interval: a possible link to the genesis of an oceanic anoxic event. Earth and Planetary Science Letters 212, 307-320.

Bate, R.H., Coleman, B.E., 1975. Upper Lias Ostracoda from Rutland and Humingdonshire. Bulletin of the Geological Survey of Great Britain 55, $1-42$.

Beerling, D.J., Brentnall, S.J., 2007. Nunerical evaluation of mechanisms driving Early Jurassic changes in global carbon cycling. Geology 35, 247-250.

Beerling, D.J., Lomas, M.R., Gröcke, D.R., 2002. On the nature of methane gashydrate dissociation during the Toarcian and Aptian oceanic anoxic events. American Journal of Science 302, 28-49.

Bizon, J.J., 1960. Sur quelques ostracodes duLias du Bassin parisien. Revue de micropaléon tologie 2, 203-211.

Bjerrum, C.J., Surlyk, F., Callomon, J.H., Slingerland, R.L., 2001. Numerical paleoceanographic study of the Early Jurassic transcontinental Laurasian seaway. Paleoceanography $16,390-404$.

Blake, J.F., 1876. Class Crustacea. In: Tate, R., Blake, J.F. (Eds.), The Yorkshine Lias. John Van Voorst, London, pp. 429-435.

Bodergat, A.M., 1997. Ostracodes marins. In: Cariou, E., Hantzpergue, P. (Eds.) pour le Groupe français d'études du Jurassique, Biostratigraphie du Jurassique ouest-européen et méditerranéen : zonations parallèles et distribution des invertébrés et microfossiles. Bulletin du centre de recherches exploraion-production Elf-Aquitaine, mémoire 17. Pau, pp. 197-223.

Bodergat, A.M., Bonnet, L., Colin, J.P., Cubaynes, R., Rey, J., 1998. Opportunis development of gmoconchamalthei (ostracod) in the lower Liassic of Quercy (SW France): an indicator of sedimentary disturbance. Palaeogeography, Palaeoclimatology, Palaeoecology 143, 179-190.

Bodergat, A.-M., Cubaynes, R., Courtenay, B., Ruget, C., 1991. Evidence of K.r and $A$ adaptative strategies in the Toarcian os tracod populations of Quercy, France. Comptes rendus de l'Académie des sciences de Paris 312, 11771182

Bodergat, A.-M., Donze, P., 1988. Biostratigraphical scale in the Toarcian of the Paris Basin by means of ostracod associations. In: Han ai, T., Ikeya, N., Ishizaki, K. (Eds.), Evolutionary biology of Ostracoda, fundamentals and applications. Froceeding of the Ninth Intemational Symposium on Ostracoda, Shizouoka, Japan, Developments in Paleontology and Stratigraphy $11,1261-1267$.

Bodergat, A.-M., Donze, P., Nicollin, J.-P., Ruget, C., 1985. Répartition biostratigraphique des microfalmes toarcienmes (foraminifères et ostracodes) en bordure du bassin de Paris. Cahiers de l'institut catholique de Lyon $14,103-121$.

Boomer, I., 1991. Lower Jurassic ostracod biozonation of the Mocbras Borehole. Journal of Micropaleontology 9, 205-218.

Boomer, I., Ainsworth, N., Exton, J., 1998. An re-examination of the Pliensbachian and Toarcian ostracod of Zambujal, west-central Portugal. Journal of Micropaleontology 17, 1-14.

Boomer, I., Ballent, S., 1996. Early-MiddleJurassic ostracod migration between the northern and southern hemispheres: further evidence for a proto AtlanticCen connection. Palaeogeography, Palaeoclimatology, Palaeoecology $121,53-64$.

Boomer, I.D., Whatley, R.C., 1992. Ostracoda and dysaerobia in the lower Jurassic of Wales: the reconstruction of past oxygen levels. Palaeogeography, Palaeoclimatology, Palaeoecology 99, 373-379.

Boutakiout, M., Donze, P., Oulmach, F., 1982. Nouvelles espèces d'osicacodes duLias moyen et supérieur du Jbel haren Nsour (rides sud-rifaines, Maroc Septentrional). Revue de micropaléontologie 25, 94-104. 
Brandt, K., 1986. Glacioeustatic cycles in the Early Jurassic? Neues Jabrbuch für Geologie und Paläontologie Monatshefte 5, 257-274.

Chandler, M.A., Rind, D., Ruedy, R., 1992. Pangaean climate during the Early Jurassic: GGCM simulations and the sedimentary record of paleoclimate. Geological Society of America Bulletin 104, 543-559.

Cohen, A.S., Coe, A.L., Harding, S.M., Schwark, L., 2004. Osmium isotope evidence for the regulation of atmospheric $\mathrm{CO}_{2}$ by continental weathering. Geology 32, 157-160

Cohen, A.S., Coe, A.L., Kemp, D.B., 2007. The Late Palaeocene and Toarcian (Early Jurassic) carbon isotope excursions: a comparison of their wime scales associate environmental changes, causes and consequences. Joumal of the Geological Society of London 164, 1097-1108.

Comas-Rengifo, M.J., Gómez, J.J., Goy, A., Herrero, C., Perilli, N., Rodrigo, A., 1999. El Jurásico Inferior en la sección de Almonacid de la Cuba (Sector central de la Cordillera Ibérica, Zaragoza, España). Cuadernos de Geología Ibérica 25, 27-57.

Coryell, H., 1963. Bibliographic index and classification of the Mesozoic os acoda. 2 Bde. University of Dayton Press, Dayton, Ohio.

Crowley, T.J., Hyde, W.T., Short, D.A., 1989. Seasonal cycle variations on the supercontinent of Pangaea. Geology 17, 457-460

Damborenea, S.E., 2000. Hispanic Corridor: its evolution and the biogeography of bivalve molluscs. GeoResearch Forum 6, 369-380

Dickens, G.R., O'Neil, J.R., Rea, D.K., Owen, R.M., 1995. Dissociation of oceanic methane hydrates as a cause of the carbon-isotope excursion at the end of the Paleocene. Paleoceanography 10,965-971.

Drexler, E., 1958. Foraminiferen und Ostracoden aus dem Lias von Siebeldingen Pfalz. Geologische Jabrbuch 75, 475-554.

Dreyer, E., 1967. Milrofossilem des Rät und Lias von SW-Brandenburg. Geologisches Jabrbuch 1, 491-531.

Elmi, S., Gabilly, J., Mouterde, R., Rulleau, L., Rocha, B., 1994. L'étage Toarcien de l'Europe et de la Téthys : divisions et corrélations. In: Cariou, E., Hantzpergue, P. (Eds.), 3r International Symposium on Jurassic stratigraphy, Poimers 1991, Geobios mémoire spécial 17, 149-159.

Elmi, S., Rulleau, L., Gabilly, J., Mouterde, R., 1997. Toarcien. In: Cariou, E., Hantzpergue, P. (Eds.) pour le Groupe français d'études du jurassique, Biostratigraphie du Jurassique ouest-européen et méditerranéen. Bulletin du cente de recherches exploration-production Elf-Aquitaine, mémoire 17. Pau, pp. 25-36

Epshteyn, O.G., 1978. Mesozoic-Cenozoic climates of northern Asia and glacial marine deposits. International Geological Review 20, 49-58.

Exton, J., 1979. Pliensbachian and Toarcian microfaunas of Zambu jal, Portugal. In: Systemaric Paleontology. Geological Paper, 79. Carleton University, pp. $1-104$.

Exton, J., Gradstein, F.M., 1984. Early Jurassic swatigraphy and micropaleontology of the Grand Banks and Portugal. In: Westermann, G.E.C. (Ed.), Jurassic and Cretaceous biochronology and biogeography of North America. Geological Association of Canada Special Paper, vol. 27. Boulder, pp. 13-28.

Frakes, L.A., Francis, J.E., Syktus, J.I., 1992. Climate modes of the Phanerozoic. Cambridge University Press, Cambridge

Fucini, A., 1935. Fossili domeriani dei dintorni di Taormina. Palaeontographia Italica $35,85-100$

Gramann, F., 1962. Skulptierte Ostracoden aus dem niederrheinischen Lias. Fortschritte in der Geologie von Rheinland und Westfalen 6, 185-198.

Gramann, F., 1963. Liasina nov. gen (os racoda) aus dem deutschen Lias. Geologische Jabrbuch A 6-74.

Gómez, J.J., 1991. Sedimentológica y paleogeografía del Jurásico en la hoja geológica no. 40 (7-5) de Daroca del Mapa Geológico deEspaña a escala de 1:200.000. ITGE, Madrid, pp. 31-82.

Gómez, J.J., Goy, A., 2000. Sequential analysis of the Toarcian in the Northern and Central-Eastern part of the Iberian subplate (Spain). In: Hall, R.L., Smith, P.L. (Eds.), Advances in Jurassic Research. GeoResearch Forum 6, 31-309.

Gómez, J.J., Goy, A., 2005. Triassic and Early Jurassic palaeogeographic evolution and depositional cycles of the Western Tethys Iberian platform system (Eastern Spain). Palaeogeography, Palaeoclimatology, Palaeoecology 222, 77-94.

Gómez, J.J., Goy, A., Canales, M.L., 2008. Seawater temperature and carbon isotope variations in belemnites linked to mass extinction during the
Toarcian (Early Jurassic) in Central and Northern Spain. Comparison with other European sectons. Palaeogeography, Palaeoclimatology, Palaeoeco$\log y 258,28-58$.

Goy, A., Comas-Rengifo, M.J., Arias, C., García Joral, F., Gómez, J.J., Herrero, C., Martínez, G., Rodrigo, A., 1997. El Tránsito Pliensbachiense/ Toarciense en el sector central de la Rama Aragonesa dela Cordillera Ibérica (España). Cabiers de l'université catholique de Lyon 10, 159-179.

Goy, A., Comas-Rengifo, M.J., Arias, C., Gómez, J.J., González, J.A., Herrero, C., Palencia, A., Perilli, N., Rodrigo, A., 2006. The Pliensbachian-Toarcian boundary in the Almonacid de la Cuba section (Iberian Range, Spain). Volumina Jurassica 4, 164-166.

Grindel, J., 1964. Zur Gattumg Healdia (Ostracoda) und verwandten Formen aus dem unteren Jura. Geologie 13, 456-477.

Guex, J., Morard, A., Bartolini, A., Morettini, E., 2001. Découverte d'une importante lacune stratigraphique à la limite Domérien-Toarcien : implications paléocéanographiques. Bulletin de la Société vaudoise des sciences naturelles $87,277-284$.

Hallam, A., 1986. The Pliensbachian and Tithonian exinction events. Nature 319, 765-768.

Hallam, A., Wignall, P.B., 1999. Mass extinctions and sea-level changes. Earth Science Reviews 48, 217-25e

Harries, P.J., 1993. Patterns of repopulation following the Cenomanian-Turonian (Upper Cretaceous) mass extinction. Ph.D. dissertation, University of Colorado, Boulder (unpublished).

Harries, P.J., Kauffman, E.G., 1990. Patterns of survival and recovery following the Cenomanian-Turonian (Late Cretaceous) mass extinction in the Western Interior Basin, United States. In: Kauffman, E.G., Walliser, O.H. (Eds.), Exinction Events in Earth History, Lecture Notes in Earth History, vol. 3 Springer-Verlag, Berlin, pp. 277-298.

Harries, P., Little, C.T.S., 1999. The early Toarcian (Early Jurassic) and the Cenomanian-Turonian (Late Cretaceous) mass extinctions: similarities and contrasts. Palaeogeography, Palaeoclimatology, Palaeoecology 154, 39-66.

Herrig, E., 1969. Ostracoden aus dem Ober-Domerien von Grimmen westlich Griefswald (Teil I). Geologie 18, 446-471.

Herrig, E., 1988. Zur Verbreitung der Ostrakoden im epikon inentalen Lias von Mittel-und West-Europa. Neues Jabrbuch für Geologie und Paläontologie Abhandlungen 176, 299-330

Hesselbo, S.P., Gröcke, D.R., Jenkyns, H.C., Bjerrum, C.J., Farrimond, P. Morgans-Bell, H.S., Green, O.R., 2000. Massive dissociation of gas hydrates during a Jurassic oceanic anoxic event. Nature 4\$6, 392-395.

Hesselbo, S.P., Jenkyns, H.C., Duarte, L.V., Oliveira, L.C.V., 2007. Carbonisotope record of the Early Jurassic (Toarcian) oceanic anoxic event from fossil wood and marine carbonate (Lusitanian Basin, Portugal). Earth and Planetary Science Letters 253, 455-470.

Jenkyns, H.C., Clayton, C.J., 1986. Black shales and carbon isotopes in pelagic sediments from the Tethyan Lower Jurassic. Sedimentology 33, 87-106.

Jenkyns, H.C., Clayton, C.J., 1997. Lower Jurassic epicontinental carbonates and mudstones from England and Wales: chemoswatigraphic signals and the early Toarcian anoxic event. Sedimentology 44, 687-706.

Jenkyns, H.C., Jones, C.E., Gröcke, D.R., Hesselbo, S.P., Parkinson, D.N., 2002. Chemostratigraphy of the Jurassic system: applications, limitations and implications for palaeoceanography. Joumal of Geological Society of London 159, 351-378.

Kemp, D.B., Coe, A.L., Cohen, A.S., Schwark, L., 2005. Astronomical pacing of methane release in the Early Jurassic period. Nature 437 , 396-399.

Kemp, D.B., Coe, A.L., Cohen, A.S., Schwark, L., 2006. Palaeoceanography: methane release in the Early Jurassic period (Reply). Nature 441, E5-E6.

Klingler, W., Neuweiler, F., 1959. Leitende Ostracoden aus dem deutschenLias. Geologische Jabrbuch A 76, 373-410

Kutzbach, J.E., Gallimore, R.G., 1989. Pangaean climates: megamonsoons of the megacontinent. Joumal of Geophysical Research 94, 3341-3357.

Little, C.T.S., 1994. The Pliensbachian-Toarcian (Lower Jurassic) Extinction Event. In: Ryder, G., Fastovsky, D., Gartner, S. (Eds.), The CretaceousTertiary Event and other catastrophes in Earth History. Geological Society of America Special Paper, vol. 307. Boulder, pp. 505-512.

Little, C.T.S., Benton, M.J., 1995. Early Jurassic mass extinction a global longterm event. Geology 23, 495-498. 
Lord, A., 1974. Ostracods from the Domerian and Toarcian of England Paleontology 17, 599-622.

Lord, A., 1978. The Jurassic. Part 1 (Hettangian-Toarcian). In: Bate, R., Robinson, E. (Eds.), A Stratigraphic Index of British Ostracoda, 8. Seel House Press, London, pp. 189-212.

Lord, A., 1982. Metacopine Ostracoda in the Lower Jurassic. In: Banner, F.T., Lord, A.R. (Eds.), Aspect of Micropalaeontology. Allen and Unwin, London, pp. 262-277.

Lord, A., 1988. Oswacoda of the Early Jurassic Tethyan Ocean. In: Hanai, T., Ikeya, N., Ishizaki, K. (Eds.), Evolutionary biology of Ostracoda: its fundamentals and applications. Proceeding of the Ninth International Symposium on Oswacoda, Shizouoka, Japan, Developments in Paleontology and Stratigraphy $11,855-867$.

Lord, A., Moorley, A., 1974. On $\bullet$ gm•conchamb sp. nov. Stereo-Atlas of oswacod shells, 2. Elsevier, pp. 9-16.

Malz, H., 1971. Zur Taxonomie "Glattschaliger" Lias Ostracoden. Senckbergiana lethaea 52, 433-455.

Martin, G.P.R., 1960. Milrofauna. In: Hoffmann, K., Martin, G.P.R. (Eds.), Die Zone des Dactylioceras tenuicostatum (Toarcien, Lias) in NW und SWDeutschland. Paleontologisches Zeitschrift, 2. pp. 103-149.

Maupin, C., 1978. Deux ostracodes nouveaux du Toarcien de Vendée (France). Geobios 11, 107-111.

McArthur, J.M., Donovan, D.T., Thirlwall, M.F., Fouke, B.W., Mattey, D., 2000 Strontium isotope profile of the early Toarcian (Jurassic) oceanic anoxic event, duration of ammonite biozones, and belemnite palaeotemperatures. Earth and Planetary Science Letters 179, 269-285.

McElwain, J.C., Wade-Murphy, J., Hesselbo, S.P., 2005. Changes in carbon dioxide during an oceanic anoxic event linke to the in usion into Gondwana coals. Nature $435,479-489$.

Page, K., 2003. The Lower Jurassic of Europe: its subdivision and correlation In: Ineson, J.R., Surlyk, F. (Eds.), The Jurassic of Denmark and Greenland. Geological Survey of Denmark and Greenland Bulletin, vol. 1. pp. 23-59.

Pálfy, J., Smith, P.L., 2000. Synchrony between Early Jurassic exinction, oceanic anoxic event, and the Karoo-Ferrar floo basalt volcanism. Geology $28,747-750$

Pálfy, J., Smith, P.L., Mortensen, J.K., 2002. Daing the end-Triassic and Early Jurassic mass extinctions, correlative large igneous provinces, and isotopic events. In: Keoberl, C., MacLeod, K.G. (Eds.), Catastrophic Events and Mass Exincions: impacts and beyond. Geological Society of America Special Paper, vol. 356. Boulder, pp. 523-532

Parrish, J.T., 1993. Climate of the supercontinent Pangea. Journal of Geology $101,215-253$.

Pietrzenuk, T., 1961. Zur Milrofauma einiger Lias vorkommen in der Deutchen Demolraschen Republik. Freiberger Forschunghelfe H(C) 113, 1-129.

Raup, D.M., Sepkoski Jr., J.J., 1986. Periodic extinctions of families and genera. Science 23, 833-836
Richter, H., 1987. Die Mikrofauna des Unteren Toarcium der Nordschweiz. Neues Jabrbuch für Geologie und Paläontologie Abhandlungen 176, 137155.

Riding, J.B., Hubbard, R.N.L.B., 1999. Jurassic (Toarcian-Kimmeridgian) dinoflagellate cysts and paleoclimates. Palynology 23, 15-30.

Riegraf, W., 1984. Neue Oswacoden-Arten aus dem Oberen Pliensbachium und Unteren Toarcium Sidwestdeutschlands und Siidfrankreichs. Stuttgarter Beitrage zur Naturkunde, Serie B 104, 1-19.

Riegraf, W., 1985. Mikrofauna, Biosmatigraphie und Fazies im Unteren Toarciaum Siidwestdeutschlands und Vergleiche mit benachbarten Gebieten. Tübinger Milopalaontologische Mitteilungen 3, 1-232.

Röbl, H., Schmid-Röbl, A., Oschmann, W., Frimmel, A., Schwark, L., 2001. The Posidonian Shale (Lower Toarcian) of SW-Germany: an oxygen depleted ecosystem controlle by sea level and palaeoclimate. Palaeogeography, Palaeoclimatology, Palaeoecology 165, 27-52.

Rosales, I., Quesada, S., Robles, S., 2004. Paleotemperature variations of Early Jurassic seawater recorded in geochemical trends of belenmites of the Basque-Cantabrian basin, northern Spain. Palaeogeography, Palaeoclimatology, Palaeoecology 203, 253-275.

Schouten, S., van Kaam-Peters, H.M.E., Rijpswa, W.I.C., Schoell, M., Damsté, J.S.S., 2000. Effects of an oceanic anoxic event on the stable carbon isotopic composition of Early Toarcian carbon. American Journal of Science 300, 1-22.

Scotese, C.R. (1991). Jurassic and Cretaceous plate tectonic reconswuctions, Palaeogeography, Palaeoclimatology, Palaeoecology 87, 493-501

SepkoskiJr., J.J., Raup, D.M., 1986. Periodicity in marine extinction events. In: Elliott, D.K. (Ed.), Dynamics of extinction. Wiley, New York, pp. 3-36.

Sepkoski, J.J., 1996. Patterns of Phanerozoic extinction: a perspective from global data bases. In: Walliser, O.H. (Ed.), Global Events and Event Stratigraphy in the Phanerozoic. Springer-Verlag, Berlin, pp. 35-51.

Svensen, H., Planke, S., Chevallier, L., Malthe-Sørenssen, A., Corfu, F., Jamtveit, B., 2007. Hydrothennal venting of greenhouse gases miggering Early Jurassic global wanning. Earth and Planetary Science Letters 256, $554-566$

Tanner, L.H., Lucas, S.G., Chapman, M.G., 2004. Assessing the record and causes of Late Triassic extinctions. Earth-Science Reviews 65, 103-139.

Van de Schootbrugge, B., McArthur, J.M., Bailey, T.R., Rosenthal, Y., Wright, J.D., Miller, K.G., 2005. Toarcian oceanic anoxic event: an assessment of global causes using belemnite $C$ isotope records. Paleoceanography 20, 2-10.

Vöros, A., 2002. Victims of the Early Toarcian anoxic event: the radiation and extinction of Jurassic Koninckinidae (Brachiopoda). Lethaia 35, 345-357.

Whatley, R.C., Arias, C., Comas-Rengifo, M.J., 1994. The use of Ostracoda in detailing kenoxic events: an example from the Spanish Toarcian. Geobios $17,733-741$

Wignall, P.B., 2001. Large igneous provinces and mass extinctions. EarthScience Reviews 53, 1-33. 